\title{
CURRENCY MISMATCHES AND PUBLIC DEBT MANAGEMENT: WHAT IS EFFECTIVE STRATEGY FOR DEVELOPING COUNTRY?
}

\author{
Scott Regifere \\ MOUANDAT
}

\author{
Economic Department, Laboratory of Applied Economics of Omar Bongo \\ University, Libreville, Gabon. \\ Email:mscottregifere@gmail.com Tel:+24106277719
}

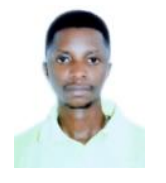

Article History
Received: 14 December 2021
Revised: 17 January 2022
Accepted: 28 January 2022
Published: 4 February 2022
Keywords
Arbitration strategy
Currency mismatches
Optimal debt management
Original sin
Domestic currency debt
Foreign currency debt
Risk premium.
JEL Classification:
C61; F31; F34.

\begin{abstract}
Developing countries are often confronted with debt problems because of the risks of over-indebtedness and especially the heavy default history. In such a context, debt management must be rigorous and guarantee a stable debt. However, such management is difficult in an environment marked by liabilities denominated in foreign currencies and assets denominated in domestic currencies, i.e., an environment of currency mismatches. The objective of this paper is then to determine, from a partial equilibrium model, an effective strategy for managing public debt in the presence of currency mismatches. We conclude that it is preferable to arbitrate between a debt denominated in foreign currency and a debt denominated in domestic currency. We also find that this arbitation depends on the financing conditions, i.e. the domestic interest rate and the risk premium on foreign debt. More precisely, when the government's objective is to minimize the interest burden, it is preferable to issue more local currency debt and less foreign currency debt, as long as the domestic interest rate is lower than the risk premium on foreign debt.
\end{abstract}

Contribution/Originality: This paper contribues to the existing literature on debt management in developing countries. We present ways in which these countries can effectively manage their debt in a context marked by currency mismatches.

\section{INTRODUCTION}

There is a consensus on the negative effects of currency mismatches on the economy in general and on public debt in particular (Eichengreen \& Hausmann, 2003; Hausmann \& Panizza, 2011; Prat, 2007), due, on the one hand, to the valuation effects of the debt burden (Carrera \& Vergara, 2012; Prat, 2007; Venkatesh \& Hiremath, 2020), on the one hand, and difficulties in managing the external debt portfolio (Hussein \& de Mello Jr, 2001), on the other hand, reflect the interest given to the issue of optimal public debt management in the presence of currency mismatches. Currency mismatches corresponds, in fact, to the difference in value between a country's national currency and the currencies in which its external public debt is denominated (Bordo, Meissner, \& Stuckler, 2016; Ranciere, Tornell, \& Vamvakidis, 2010). This is precisely the situation in a country where the state's commitments are denominated in one (or more) hard currencies, whereas its income is denominated in national currency (Goldstein \& Turner, 2004).

Public debt management is defined, for its part, as a strategy to ensure that the government's financing needs and repayment obligations are met with a minimum of risk (Togo, 2007). 
It is said to be optimal when it takes into account either social objectives or economic stimulation objectives ${ }^{1}$. Optimal public debt management is therefore concerned with the optimal debt structure, either in terms of maturity (Angeletos, 2002; Buera \& Nicolini, 2004) or in terms of currency (Melecky, 2012; Papaioannou, 2009), that is, a structure that improves social or economic conditions. The analysis of public debt management is central to government strategies, in this case in an environment where a significant proportion of public debt is denominated in foreign currencies and, above all, where governments can only obtain international loans in foreign currency ${ }^{2}$ (Hausmann \& Panizza, 2011). Thus, the problem of optimal public debt management in the presence of currency mismatches is broadly based on two lines of research:

$\left.1^{\circ}\right)$ The first line of research relates to the difficulties of repaying interest payments when a depreciation of the national currency occurs (Jankovic \& Zivković, 2014; Prat, 2007; Ranciere et al., 2010).

$2^{\circ}$ ) The second axis focuses on the management of exchange rate risk relating to external debt (Melecky, 2008; Papaioannou, 2009).

With regard to the first line of research, the presence of currency mismatches increases the value of external debt service and is therefore likely to lead to sovereign default in a situation of depreciation of the national currency, because of the increase in interest expense. The accumulation of foreign currency-denominated external liabilities while income (or assets) continue to be denominated in national currency thus causes financial fragility (Yilmaz, 2018) that can lead, in extreme cases, to self-fulfilling expectations of exchange rate depreciation on the part of investors. However, such a depreciation also increases the value of exports ${ }^{3}$ (Svensson, 2000) and therefore affects the capacity to repay external debt service ${ }^{4}$. In this respect, two situations are generally desirable : (a) that the currency structure of public debt and exports be in the same proportions ${ }^{5}$; (b) that export gains are higher than the consequences of a depreciation on debt denominated in foreign currency.

It should be noted that there is a majority consensus in the literature that a depreciation of the domestic currency is detrimental to public finances (Venkatesh \& Hiremath, 2020; Yilmaz, 2018). The presence of currency mismatches in fact promotes a feeling of mistrust on the part of international lenders (loss of confidence), or even a massive outflow of foreign capital that forces public debt financing when an appreciation of the currency in which external debt is denominated occurs (Bordo et al., 2016; Calvo, Izquierdo, \& Mejia, 2008). Such a situation generally leads to a reduction in the government's rating by rating agencies and favours an increase in risk premiums (Carrera \& Vergara, 2012).

Thus, through the foreign currency debt and the exchange rate risk that characterizes it, it is a source of a crisis of confidence in the State's capacity to repay its commitments and to be able to refinance itself. This situation (crisis of confidence) is at the origin of a sudden stop in capital flows, which translates into an increase in "sovereign spreads6", i.e. interest rate differentials (Jankovic \& Zivković, 2014; Prat, 2007).

Such an explanation stems from the fact that servicing foreign currency debt implies releasing foreign currency resources over a long period of time (Hausmann \& Panizza, 2011). An investor will lend only to the extent that it has a positive judgment of the government's ability to repay its debts in the long term and to have the foreign currency to service its foreign currency debt. Investor perception thus appears to be an essential variable that

\footnotetext{
${ }^{1}$ The social objectives are mainly based on three independent objectives. These may be maximizing the welfare of households, maximizing the wealth of private agents, or minimizing the cost of indebtedness. The economic objectives are based either on maximizing Tobin's q or on maximizing firm investment.

${ }^{2}$ Phenomenon referred to as "original sin" (Eichengreen \& Hausmann, 2003).

${ }^{3}$ If the "critical elasticity conditions" are met, i.e. if the sum of the absolute values of the price elasticities of the export and import applications is greater than unity.

${ }_{4}^{4}$ The effect of a depreciation on public debt will therefore depend on the degree of currency mismatches, the amount and maturity of the debt, the exchange rate

regime, the degree of openness of the local market, the opportunities for increasing exports and the balance of payments situation (Jankovic \& Zivković, 2014).

${ }_{5}^{5}$ To ensure that the increased debt burden is offset by gains in external competitiveness to reduce the likelihood of a sovereign debt crisis.

${ }^{6}$ The work is also interested in the link between currency mismatches, lender sentiment, sovereign spreads and the probability of default (Prat, 2007).
} 
determines the timing of the debt crisis, since the reversals in capital flows that it favours lead to discontinuities in market access. With regard to the second line of research, the management of public debt in a situation of currency mismatches focuses, in fact, on the management of exchange rate risk because of the presence of large shares of foreign currency debt in government portfolios (Melecky, 2008; Papaioannou, 2009).

Thus, the development of the domestic financial market becomes an alternative to the efficient management of such a risk. Such a development allows governments to resort, on the one hand, to debt in domestic currency and, on the other hand, to hedging by derivatives ${ }^{7}$ (Melecky, 2008).

Indeed, local currency debt has three advantages: it reduces the effects of exchange rate fluctuations on the external debt portfolio, it is independent of borrowing in foreign currencies, and finally, it gives governments the capacity to influence its value through inflation (Aizenman \& Marion, 2011). As for derivatives, they are the main hedging instrument in the financial markets because of their advantages in terms of freedom to negotiate debt contracts. From then on, we are led to ask ourselves the following question: How can optimal management of public debt be guaranteed in a situation of currency mismatches?

The purpose of this article is then to determine, through a partial equilibrium model, an optimal public debt management strategy. It is precisely a question of participating in the debate on the relevance of debt in domestic currency (Artus, 2003; Prasetyo \& Yoshino, 2015), and by extension on the interest of developing local financial markets (Burger, Warnock, \& Warnock, 2012). The article thus shows how public debt managers should conduct their activity in the presence of currency mismatches, when the objective of public debt management is centred on minimising interest payments. It concludes that optimal management in this context depends on financing conditions, in particular the interest rate and the risk premium of external creditors.

Thus, the originality of the article is to propose the possibility to make a compromise between the two types of debt considering currency mimsmatches. In fact, even in the presence of this phenomenon, it is always possible to have recourse to both foreign and domestic currency denominated debt. This result goes completely against the original sin literature as Hausmann and Panizza (2011), attest that only the development of the domestic debt market, hence domestic debt, can protect against the exchange rate risk associated with the presence of a large amount of foreign currency debt. In particular, the article shows the conditions for such a compromise.

The rest of the article is composed of the model (part two), lessons from model (part three), implications (part four) and a conclusion (last part).

\section{THE MODEL}

We rely on the model of Prasetyo and Yoshino (2015), which analyzes the optimal management of public debt in the Indonesian economy. Like Prasetyo and Yoshino (2015), we assume the existence of two types of debt: domestic debt and external debt. We assume that domestic debt is denominated in domestic currency. Such a choice is all the more consistent since there is no category of "domestic bonds in foreign currency" in developing economies because of the low development of domestic financial markets (Blommestein \& Santiso, 2007). External debt, for its part, is assumed to be entirely denominated in foreign currency in order to integrate the original sin hypothesis (Eichengreen \& Hausmann, 2003). Such a configuration makes it possible to justify the presence of riskaverse investors and thus risk premiums.

Unlike Prasetyo and Yoshino (2015), the government's objective (the management of public debt) focuses only on minimizing interest payments. We therefore consider a small open economy where three types of agents interact: second-tier banks, households and the government, whose behaviour we now describe.

\footnotetext{
${ }_{7}^{7}$ Derivatives are products whereby two counterparties have the ability to trade forward (at a future date set by the contract between the two counterparties) an underlying financial asset (bond, commodity, stock, currency, etc.) on the spot side of financial markets.
} 


\subsection{The Behaviour of Banks}

We consider a representative bank whose assets are made up of reserves $(\mathrm{R})$, loans $\left(L^{S}\right)$ and government debt $\left(B^{B}\right)$, and whose liabilities are made up of deposits $\left(D^{S}\right)$. The bank's reserves are linked to a fraction of deposits $\left(\rho D^{s}\right)$ and excess reserves $(\mathrm{ER})$. The bank's budgetary constraint is then written:

$$
\rho D_{t}^{S}+E R_{t}+L_{t}^{S}+B_{t}^{B}=D_{t}^{S}
$$

Equation 1 in effect represents the representative bank's budget constraint. It tracks its assets and liabilities. By rearranging Equation 1 we obtain the equation of available deposits:

$$
E R_{t}+L_{t}^{s}+B_{t}^{B}=(1-\rho) D_{t}^{s}
$$

Equation 2 highlights the expression for deposits available at the bank.

The excess return fraction of available deposits $(\varepsilon)$ is a function of the interest rate on government debt $\left(\boldsymbol{r}_{t}\right)$, since the bank could incorporate it into risk-free assets ; while the loan fraction related to deposits (l) is a function of loans interest rate $\left(r_{t}^{L}\right)$ and interest rate $\left(r_{t}\right)$. Excess reserves and loan supply are represented as follows:

$$
\begin{aligned}
& E R_{t}=\varepsilon\left(r_{t}\right)(1-\rho) D_{t}^{S} \\
& L_{t}^{S}=l\left(r_{t}, r_{t}^{L}\right)(1-\rho) D_{t}^{S}
\end{aligned}
$$

Equations 3 and 4 are excess reserves and the loan supply of the representative bank, respectively. They determine the bank's ability to refinance itself Equation 3 as well as the amount of loans it is willing to grant Equation 4.

From Equation 1, we obtain the banks' demand for government debt:

$$
B_{t}^{B}=(1-\rho) D_{t}^{S}-E R_{t}-L_{t}^{S}
$$

Equation 5 highlights the amount of public debt the bank needs, in other words, its demand for government debt as mentioned above.

The granting of credit and the collection of deposits by the bank raises the question of the reserve ratio, that is, the value of the reserve/deposit ratio, represented as follows:

$$
\frac{R_{t}}{D_{t}^{s}}=\rho+\varepsilon\left(r_{t}\right)(1-\rho)=\frac{1}{\mu\left(r_{t}\right)}
$$

Equation 6 shows that the reserve/deposit ratio is the sum of the reserve requirement and the fraction of return on available deposits multiplied by the available rate $(1-\rho)$ which is equal to the inverse of the money multiplier $\mu\left(r_{t}\right)$.

Thus, since the bank is at the origin of money creation, we deduce that the supply of money available to households $\left(M_{t}^{S}\right)$ equals the supply of deposits $\left(D_{t}^{S}\right)$ as in the following expression:

$$
M_{t}^{s}=D_{t}^{s}=\mu\left(r_{t}\right) R_{t}
$$

Equation 7 shows the quantity of money offered in the domestic economy, resulting from the money creation activity of the representative bank.

\subsection{Household Behaviours}

We consider a representative household whose assets are composed of deposits $\left(D^{D}\right)$ and the purchase of public debt $\left(B^{N}\right)$, while its liabilities are composed of bank loans $\left(L^{D}\right)$. The difference between their assets and liabilities is their net financial wealth $(\mathrm{W})$. The household budget constraint is then written as:

$$
D_{t}^{D}+B_{t}^{N}=L_{t}^{D}+W_{t}
$$

Equation 8 represents the budget constraint of the representative household. It shows how the household allocates its income, which allows us to assess its net financial wealth.

The demand for money $\left(M_{t}^{D}\right)$ is a function of the interest rate on loans $\left(r_{t}\right)$, income $\left(y_{t}\right)$ and net wealth $\left(w_{t}\right)$. The loan supply $\left(L_{t}^{D}\right)$ is then a function of $\left(r_{t}\right),\left(r_{t}^{L}\right)$ and $\left(y_{t}\right)$, i.e.: 


$$
\begin{aligned}
& M_{t}^{D}=D_{t}^{D}=D\left(r_{t}, y_{t}, W_{t}\right) . \\
& L_{t}^{D}=L\left(r_{t}, r_{t}^{L}, y_{t}\right) .
\end{aligned}
$$

Equations 9 and 10 represent the demand for money and the supply of loans, respectively.

Furthermore, financial wealth at $\mathrm{t}$ is defined as:

$$
W_{t}=W_{t-1}+S_{t}
$$

Equation 11 shows that the financial wealth of the representative household consists of its accumulated financial wealth in the past period plus savings in the current period.

$$
\text { However, } S_{t}=(1-\tau) y_{t}-C\left[(1-\tau) y_{t}\right] \text {. }
$$

with, $\tau$ the tax rate.

Equation 12 represents savings, which is considered here as an accumulation equal to disposable income minus consumption (consumption being a function of the tax rate and income).

Substituting Equations 9 to 12 into Equation 8 yields household demand for government debt:

$B_{t}^{N}=W_{t}+L_{t}^{D}-D_{t}^{D}=W_{t-1}+(1-\tau) y_{t}-C\left[(1-\tau) y_{t}\right]+L\left(r_{t}, r_{t}^{L}, y_{t}\right)-D\left(r_{t}, y_{t}, W_{t}\right)(13)$

From the public debt demands of banks and households (representing the non-financial private sector), domestic demand for government debt is defined. It is the sum of the demands when the money market and the credit market are in equilibrium Equations 14 and 15 represent these equilibria respectively). The total demand for government debt is given by Equation 17 below:

$$
\begin{aligned}
& \mu\left(r_{t}\right) R_{t}=D\left(r_{t}, y_{t}, W_{t}\right) ; \\
& l\left(r_{t}, r_{t}^{L}\right)(1-\rho) D_{t}^{S}=L\left(r_{t}, r_{t}^{L}, y_{t}\right) ; \\
& B_{t}^{D} \equiv B_{t}^{N}+B_{t}^{B} ; \\
& B_{t}^{D}=W_{t}-R_{t}=W_{t}-\rho D_{t}-\varepsilon\left(r_{t}\right)(1-\rho) D_{t}
\end{aligned}
$$

\subsection{The Behaviour of the Government}

We suppose, on the one hand, the existence of the original sin of the fact that the demand for the foreign debt is linked to foreign creditors. Such an assumption highlights the risk aversion of these agents, who prefer to denominate their loans in their own currencies or, more generally, in the main foreign currencies (US dollar, euro, yen, Swiss franc and pound sterling) (Goldberg \& Tille, 2016). Foreign demand for the government's foreign debt is a function of the risk premium $(\theta)$, changes in domestic income $(\Delta y)$ and changes in foreign income $\left(\Delta y^{f}\right)$.

The risk premium is nothing more than the income that remunerates foreign investors for taking a risk. Its level depends on the credit they grant to the domestic government in relation to debt repayment (Jankovic \& Zivković, 2014; Prat, 2007). As for variations in income, the literature admits that they are intimately linked to the determination of a state's solvency (Carrera \& Vergara, 2012).Considering the interest rate parity relationship as in Carrera and Vergara (2012), the risk premium is defined as the difference between the interest rate on domestic debt and the risk-free rate $\left(r^{*}\right)$, which is affected by the expected exchange rate $\left[E\left(e_{t+1}\right)\right]$. In addition, national income would depend on the interest rate on government bonds, the borrowing rate, and government spending in each country. Note that all other variables affecting the demand for external public debt are exogenous, except for domestic and foreign interest rates.

$$
\begin{aligned}
& Q_{t}^{F}=B^{F}\left(r_{t}, r_{t}^{f}, e_{t}, y_{t}, y_{t}^{t}\right) \quad \text { (foreign demand for foreign debt) } \\
& r_{t}=r^{*}+E\left(e_{t+1}\right)+\theta_{t}=r_{t}^{f} \quad \text { (unhedged interest rate parity) } \\
& y_{t}=y\left(r_{t}, G_{t}, e_{t}\right) \quad \text { (domestic income) }
\end{aligned}
$$


Equations 18, 19, and 20, respectively, represent foreign demand for the representative government's external debt (which is a function of domestic and foreign interest rates, domestic and foreign income, and the exchange rate), uncovered interest rate parity, and domestic income (a function of the domestic interest rate, government spending, and the exchange rate).

On the other hand, one of the government's main considerations in determining the amount of debt is the fiscal constraint on the primary balance. The government's revenues come from taxes $(\tau y)$ and new debt $\left(\Delta B_{t}\right)$.

On the other hand, the government has expenditures $(G)$ and must repay the interest on previous borrowing. The government's budgetary constraint is expressed as follows:

$$
\tau y_{t}+\Delta B_{t}=G_{t}+\left[r_{t-1}+r_{t-1}^{f} e_{t-1}\right] \overline{B_{t-1}} .
$$

with, $B_{t-1}$ the outstanding public debt of the previous period.

Equation 21 shows how the representative government allocates its expenditures according to its resources. This is its budget constraint.

We know, on the other hand, that the new stock of debt is the accumulation of outstanding debt and newly issued debt, i.e.:

$$
B_{t} \equiv \overline{B_{t-1}}+\Delta B_{t}
$$

Such as, $B_{t}=B_{t}^{G}+B_{t}^{F}$,

with, $B_{t}, B_{t}^{G}$ and $B_{t}^{F}$ public debt, domestic debt and external debt, respectively.

By rearranging Equation 21, from Equation 22, we obtain the following expression:

$$
\tau y_{t}+B_{t}^{G}+e_{t} B_{t}^{F}=G_{t}+\left[r_{t-1}+r_{t-1}^{f} e_{t-1}\right] \overline{B_{t-1}}+\overline{B_{t-1}} .
$$

Equation 23 captures well a currency-asymmetric situation, i.e. a situation where part of the government's debt is denominated in foreign currency, while the other part and the revenues are denominated in domestic currency.

On the other hand, the determination of the optimal structure of public debt, that is, the optimal management of public debt, must take into account the dynamic situation in both markets (the domestic and foreign public debt markets), as follows:

$$
\begin{aligned}
& B_{t}^{G}=W_{t}-\rho D_{t}-\varepsilon\left(r_{t}\right)(1-\rho) D_{t}, \\
& e_{t} B_{t}^{F}=B^{F}\left(r_{t}, r_{t}^{f}, e_{t}, y_{t}, y_{t}^{t}\right)
\end{aligned}
$$

Thus, the government sees balance in both markets as a constraint to achieving its objective. Domestic market equilibrium is achieved when the partial domestic supply of government debt is equal to the sum of the demand for government bonds from banks and households Equation 24. Similarly, the external bond market is in equilibrium when the partial external supply of government bonds equals the demand for external bonds Equation 25. Note that the exchange rate plays an important role in foreign currency denomination. In fact, the government's decisions in determining the level of external debt affect the value of the exchange rate.

In international foreign exchange markets, the supply of foreign currency $\left(Q_{t}^{S}\right)$ is provided by exports (Xt) and capital inflows, while the demand for foreign currency $\left(Q_{t}^{d}\right)$ is determined by imports $(\mathrm{Mt})$ and capital outflows. The capital inflow comes from new debt $\left(e_{t} B_{t}^{F}\right)$ and the capital outflow is the amount of existing debt plus its interest $\left\{\left(1+r_{t-1}^{f}\right) e_{t} B_{t-1}^{F}\right\}$.

We then have:

$$
\begin{aligned}
& Q_{t}^{S}=X_{t}+e_{t} B_{t}^{F} \\
& Q_{t}^{d}=M_{t}+\left\{\left(1+r_{t-1}^{f}\right) e_{t} B_{t-1}^{F}\right\}
\end{aligned}
$$


Equations 26 and 27 represent the supply (which depends on the volume of exports and foreign currency debt) and demand for money (which is a function of the volume of imports and previous foreign debt plus interest) in the capital market, respectively.

At equilibrium, the value of the exchange rate is formulated as follows:

$$
e_{t}=\frac{M_{t}-X_{t}}{B_{t}^{F}-\left\{\left(1+r_{t-1}^{f}\right) B_{t-1}^{F}\right\}}
$$

Equation 28 shows the value of the current exchange rate in equilibrium (between money supply and demand in the international capital market). It is evaluated by the ratio of the trade deficit to the current and previous foreign currency debt and interest differential.

\subsection{Determining the Equilibrium of the Model}

It is a question of minimizing the interest of payments under the constraints of Equations 23, 24 and 25. Its program $(\mathrm{P})$ is as follows:

$$
(P):\left\{\begin{array}{c}
\operatorname{Min} B_{t}^{G}+e_{t} B_{t}^{G}-\overline{B_{t-1}}-e_{t} \overline{B_{t-1}}+\left[r B_{t}^{G}+B_{t}^{F} r_{t}^{f} E\left(e_{t+1}\right)\right] \frac{1}{1+E\left(r_{t+1}\right)} \\
S / C \\
\tau y_{t}+B_{t}^{G}+e_{t} B_{t}^{F}=G_{t}+\left[r_{t-1}+r_{t-1}^{f} e_{t-1}\right] \overline{B_{t-1}}+\overline{B_{t-1}} \\
B_{t}^{G}=W_{t}-\rho D_{t}-\varepsilon\left(r_{t}\right)(1-\rho) D_{t} \\
e_{t} B_{t}^{F}=B^{F}\left(r_{t}, r_{t}^{f}, e_{t}, y_{t}, y_{t}^{f}\right)
\end{array}\right.
$$

with, $\frac{1}{1+E\left(r_{t+1}\right)}$, the discount factor that discounts the interest on payments.

We proceed with the Lagrange method to solve the government's program. We then consider the necessary conditions as sufficient conditions because we assume that the Lagrangian (L) associated with our program is concave. Let $\varphi_{t} \delta_{t}$ and $\lambda_{t}$ be the multipliers associated with the program constraints, the conditions of optimality are as follows:

$$
\left\{\begin{array}{l}
\frac{B_{t}^{G}}{1+E\left(r_{t+1}\right)}=-\lambda_{t} \frac{\partial B^{F}}{\partial r_{t}} \\
\frac{B_{t}^{F} E\left(e_{t+1}\right)}{1+E\left(r_{t+1}\right)}=-\lambda_{t} \frac{\partial B^{F}}{\partial r_{t}^{f}} \\
\tau y_{t}+B_{t}^{G}+e_{t} B_{t}^{F}=G_{t}+\left[r_{t-1}+r_{t-1}^{f} e_{t-1}\right] \overline{B_{t-1}}+\overline{B_{t-1}} \\
B_{t}^{G}=W_{t}-\rho D_{t}-\varepsilon\left(r_{t}\right)(1-\rho) D_{t} \\
e_{t} B_{t}^{F}=B^{F}\left(r_{t}, r_{t}^{f}, e_{t}, y_{t}, y_{t}^{t}\right)
\end{array}\right.
$$

Proceeding from the relationship between Equation 29 and Equation 30, he comes to:

$$
\begin{aligned}
& \frac{B_{t}^{G}}{B_{t}^{F} E\left(e_{t+1}\right)}=d r \quad \text { with, } d r=\frac{\partial r_{t}^{f}}{\partial r_{t}} \\
& B_{t}^{F}=\frac{B_{t}^{G}}{d r E\left(e_{t+1}\right)} .
\end{aligned}
$$

Equation 35 gives the value of foreign currency debt (external debt) in terms of domestic debt. Let us replace its value in Equation 31, which represents the government's budgetary constraint. We have:

$$
B_{t}^{G}+e_{t}\left(\frac{B_{t}^{G}}{\operatorname{drE}\left(e_{t+1}\right)}\right)=D B_{t},
$$

$D B_{t}$, refers to the current budget deficit. Its expression is given by the following equation ${ }^{9}$ :

${ }^{9}$ This is a reorganization of Equation 31. 


$$
D B_{t}=G_{t}+\left[r_{t-1}+r_{t-1}^{f} e_{t-1}\right] \overline{B_{t-1}}+\overline{B_{t-1}}-\tau y_{t}
$$

Thus,

$$
B_{t}^{G}=\frac{D B_{t} d r E\left(e_{t+1}\right)}{d r E\left(e_{t+1}\right)+e_{t}}
$$

The value of the exchange rate is determined by Equation 28. By rearranging Equation 38, we obtain the expression of the optimal structure of the domestic debt:

$$
B_{t}^{G}=\frac{D B_{t} d r E\left(e_{t+1}\right)\left[B_{t}^{F}-\left(1+r_{t-1}^{f}\right) B_{t-1}^{F}\right]}{B_{t}^{F}-\left(1+r_{t-1}^{f}\right) B_{t-1}^{F}+Z_{t}}
$$

$Z_{t}=M_{t}-X_{t}$, being the trade deficit in the current period, i.e. the difference between imports in the current period $(\mathrm{Mt})$ and exports in the same period $(\mathrm{Xt})$.

Equation 39 is the expression of the domestic debt as a function of the foreign debt and is expressed in the following functional form:

$$
B_{t}^{G}=f\left(B_{t}^{F}\right)=\frac{s B_{t}^{F}-a}{B_{t}^{F}-b},
$$

with:

$a=s\left[\left(1+r_{t-1}^{f}\right) B_{t-1}^{F}\right]$;

$b=\left(1+r_{t-1}^{f}\right) B_{t-1}^{F}+Z_{t} \quad$ and

$s=D B_{t} d r E\left(e_{t+1}\right)$.

Equation 40 is the equilibrium equation of the model. It clearly traces the relationship between domestic and external debt in the presence of currency mismatches, when the government's objective is to minimize interest payments. The differential with respect to $B_{t}^{F}$ can be calculated as:

$$
\begin{aligned}
\frac{d B_{t}^{G}}{d B_{t}^{F}} & =-\frac{(s b-a)}{\left(B_{t}^{F}-b\right)^{2}} . \\
\frac{d B_{t}^{G}}{d B_{t}^{F}} & =\frac{-\left[s\left(\left(1+r_{t-1}^{f}\right) B_{t-1}^{F}+Z_{t}\right)-s\left(1+r_{t-1}^{f}\right) B_{t-1}^{F}\right]}{\left(B_{t}^{F}-b\right)^{2}} \\
\frac{d B_{t}^{G}}{d B_{t}^{F}} & =\frac{-s Z_{t}}{\left(B_{t}^{F}-b\right)^{2}}
\end{aligned}
$$

such as:

$$
\begin{gathered}
d r=\frac{\partial r_{t}^{f}}{\partial r_{t}}<0 \text { and } Z_{t}>0 \\
\frac{d B_{t}^{G}}{d B_{t}^{F}}>0
\end{gathered}
$$

In the case of a trade balance deficit, if the foreign and domestic interest rates on the loan move in opposite directions, then the domestic and foreign indebtedness move in the same direction. Equation 44 already denotes a strategy of using both instruments in the process of public indebtedness.

However, revealing the government's optimal management strategy when its objective is to minimize the interest on payments in the presence of currency mismatches leads us to study this relationship.

From this study, we obtain Figure 1. This Figure shows the relationship between debt in domestic currency $\left(B_{t}^{G}\right)$ on the $\mathrm{y}$-axis and debt in foreign currency $\left(B_{t}^{F}\right)$ on the x-axis. The lines $(\mathrm{D} 1)$ and $(\mathrm{D} 2)$ correspond respectively to the horizontal and vertical asymptotes. 


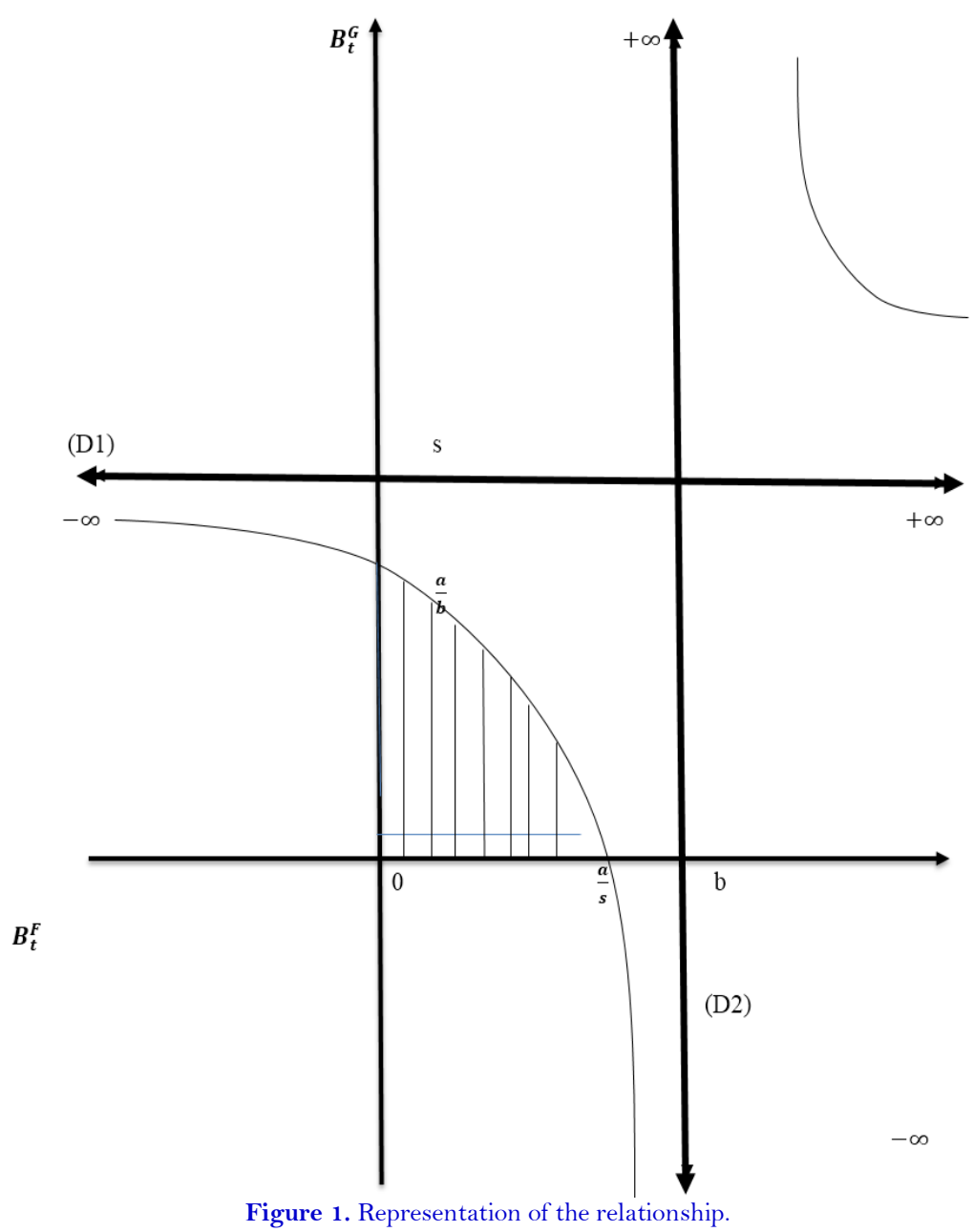

\section{LESSONS FROM THE MODEL}

The study of the relationship and especially the configuration of Figure 1 allow us to draw two lessons:

$1^{\circ}$ ) The first lesson relates to the limits of domestic and foreign indebtedness.

$2^{\circ}$ ) The second lesson relates to public debt management strategies.

\subsection{Debt Limits in Domestic and Foreign Currencies}

With regard to the first lesson, it can be seen that the line (D1) of the Figure represents the theorical limit of the government's domestic debt when the foreign debt increases indefinitely (to infinity). This limit is $\mathrm{s}$, that is, the foreign currency value of the budget deficit multiplied by the ratio of interest rate changes. It is determined by the horizontal line (horizontal asymptote) as follows:

The value $\mathrm{b}$, on the abscissa, which corresponds to the interest payment on the external debt of the previous period plus the trade deficit, represents the theorical limit of the external debt that the government should not exceed if domestic indebtedness increases to near infinity. The values $s$ and $b$, then, are finite limits of the two types of debt when one or the other increases indefinitely.

\subsection{Public Debt Management Strategies}

The second lesson of the model is that there are two categories of strategies: what we call radical strategies, on the one hand, and prudent strategies, on the other. 
Radical strategies involve determining how much debt the government should incur if it wants to minimize its interest payments when any one financing is totally preferred.

Point $(0 ; a / b)$ reveals that if domestic debt is considered totally at the expense of foreign currency debt, the government must limit itself to a debt equal to the $\mathrm{a} / \mathrm{b}$ ratio if it wants to minimize interest payments. Note that this amount is lower than the limit of domestic debt $(\mathrm{a} / \mathrm{b}<\mathrm{s})$. This situation would correspond to a perfect "redemption" of the original sin due to the total absence of the debt denominated in foreign currency. On the other hand, point $(\mathrm{a} / \mathrm{s} ; \mathrm{O})$, which reveals a contrary strategy, shows that if it is the external debt that is totally privileged, the debt contracted must be equal to $\mathrm{a} / \mathrm{s}$, that is, to the interest payments on the external debt ${ }^{10}$. It should also be noted that this amount does not exceed the limit of foreign currency debt represented by the value $b$.

However, evidence of stylized facts shows that governments still give preference to both instruments (domestic currency debt/foreign currency debt) in their public debt management strategy relative to the monetary structure of the portfolio. In this configuration, radical strategies are not optimal strategies for managing public debt in the presence of currency mismatches. The prudent strategy, which defines the government's optimal strategy, makes it possible to highlight the various cases that minimize the cost of the public debt by determining the area (A) of the hatched part of the curve :

$$
A=\int_{0}^{\frac{a}{s}} f\left(B_{t}^{F}\right) d B_{t}^{F}=\int_{0}^{\frac{a}{s}} \frac{s B_{t}^{F}-a}{B_{t}^{F}-b} d B_{t}^{F}
$$

or, $\frac{s B_{t}^{F}-a}{B_{t}^{F}-b}=s+\frac{s b-a}{B_{t}^{F}-b}$, by euclidian division,

thus,

$$
\int_{0}^{\frac{a}{s}} f\left(B_{t}^{F}\right) d B_{t}^{F}=\int_{0}^{\frac{a}{s}}\left(s+\frac{s b-a}{B_{t}^{F}-b}\right) d B_{t}^{F}
$$

The primitive $(\mathrm{F})$ of $(\mathrm{f})$ is written as follows:

$$
F\left(B_{t}^{F}\right)=s B_{t}^{F}+(s b-a) \ln \left|B_{t}^{F}-b\right|+C,
$$

with $\mathrm{C}$ a positive constant.

Equation 46 becomes:

$$
\begin{aligned}
& A=\int_{0}^{\frac{a}{s}}\left(s+\frac{s b-a}{B_{t}^{F}-b}\right) d B_{t}^{F}=\left[s B_{t}^{F}+(s b-a) \ln \left|B_{t}^{F}-b\right|+C\right]_{0}^{\frac{a}{s}} \\
& A=\int_{0}^{\frac{a}{s}}\left(s+\frac{s b-a}{B_{t}^{F}-b}\right) d B_{t}^{F}=a+(s b-a) \ln \left|\frac{a}{s}-b\right|-(s b-a) \ln b
\end{aligned}
$$

because, $\ln |-b|=\ln b, \forall b \in] b ;+\infty[$.

Such:

$a=s\left[\left(1+r_{t-1}^{f}\right) B_{t-1}^{F}\right]$

$b=\left(1+r_{t-1}^{f}\right) B_{t-1}^{F}+Z_{t} \quad$ and

$s=D B_{t} d r E\left(e_{t+1}\right)$, thus:

${ }^{10}$ In fact, $\frac{a}{s}=\frac{D B_{t} d r E\left(e_{t+1}\right)\left[\left(1+r_{t-1}^{f}\right) B_{t-1}^{F}\right]}{D B_{t} d r E\left(e_{t+1}\right)}=\left[\left(1+r_{t-1}^{f}\right) B_{t-1}^{F}\right]$ 


$$
\begin{aligned}
& A=s\left(1+r_{t-1}^{f}\right) B_{t-1}^{F}+\left[D B_{t} d r E\left(e_{t+1}\right)\left(1+r_{t-1}^{f}\right) B_{t-1}^{F}+Z_{t}\right] \ln \mid \frac{s\left(1+r_{t-1}^{f}\right) B_{t-1}^{F}}{s}-\left(1+r_{t-1}^{f}\right) B_{t-1}^{F}- \\
& Z_{t} \mid-\left[D B_{t} d r E\left(e_{t+1}\right)\left[\left(1+r_{t-1}^{f}\right) B_{t-1}^{F}+Z_{t}\right]-D B_{t} d r E\left(e_{t+1}\right)\left(1+r_{t-1}^{f}\right) B_{t-1}^{F}\right] \ln b
\end{aligned}
$$

$$
A=D B_{t} d r E\left(e_{t+1}\right)\left(1+r_{t-1}^{f}\right) B_{t-1}^{F}+V_{t}
$$

with:

$$
\begin{aligned}
& V_{t}=\left[D B_{t} d r E\left(e_{t+1}\right)\left(1+r_{t-1}^{f}\right) B_{t-1}^{F}+Z_{t}\right] \ln \left|\frac{s\left(1+r_{t-1}^{f}\right) B_{t-1}^{F}}{s}-\left(1+r_{t-1}^{f}\right) B_{t-1}^{F}-Z_{t}\right|- \\
& {\left[D B_{t} d r E\left(e_{t+1}\right)\left[\left(1+r_{t-1}^{f}\right) B_{t-1}^{F}+Z_{t}\right]-D B_{t} d r E\left(e_{t+1}\right)\left(1+r_{t-1}^{f}\right) B_{t-1}^{F}\right] \ln b}
\end{aligned}
$$

Given that in the long run, interest rates often show limited volatility, we assume that the domestic interest rate $\left(r_{t}\right)$ is equal to the foreign interest rate $\left(r_{t}^{f}\right)$. This allows us to pose $(\mathrm{dr}=1)$.

Furthermore, at a risk-free interest rate of zero, the unhedged interest rate parity relationship gives the expression of the expected future exchange rate ${ }^{11}$.

Thus, Equation 50 becomes:

$$
A=\left(r_{t}-\theta_{t}\right)\left[D B_{t}\left(1+r_{t-1}^{f}\right) B_{t-1}^{F}\right]+V_{t}
$$

Equation 51 shows that optimal debt management in the presence of currency mismatches depends on the behaviour of the domestic interest rate and the risk premium ${ }^{12}$, i.e. the arbitrage between the two public debt instruments according to financing conditions.

The predominance of one or the other type of financing ${ }^{13}$ depends on three cases when the government's objective is to minimize interest payments :

Case 1: $r_{t}-\theta_{t}<0$, the government has to issue more domestic debt and less foreign currency debt because the domestic interest rate is lower than the risk premium that exists because of investors' risk aversion.

Case 2: $r_{t}-\theta_{t}>0$, the government adopts a strategy contrary to case 1 . It must issue more foreign currency debt and less domestic debt.

Case 3: $r_{t}-\theta_{t}=0$, the government's optimal strategy would be to issue equivalent amounts of domestic and external debt. Such a strategy allows the public debt portfolio to be equally weighted.

Thus, in the light of these three cases, the optimal strategy for public debt management in the presence of currency mismatches is generally to give preference to both types of instrument, i.e. both domestic currency debt (domestic debt) and foreign currency debt (external debt). Except that the predominance of one of the debts in the portfolio will depend on the associated costs, notably the domestic interest rate and the risk premium on external debt. Such a risk premium is, in general, the variable that increases the cost of foreign currency debt because of the risk-averse behavior of international investors. In fact, when debt increases or approaches a limit it affects risk

$$
\begin{aligned}
& { }_{11} E\left(e_{t+1}\right)=r_{t}-\theta_{t} \\
& { }^{12} \text { Since the term } \frac{D B_{t}\left[\left(1+r_{t-1}^{f}\right) B_{t-1}^{F}\right]\left[\left(1+r_{t-1}^{f}\right) B_{t-1}^{F}\right]}{2\left[\left(1+r_{t-1}^{f}\right) B_{t-1}^{F}+Z_{t}\right]} \text { is a constant. }
\end{aligned}
$$

${ }^{13}$ Without however giving up the other one since we are in the weak strategy, i.e. the hatched area of the chart. 
premiums upwards. The increase in risk premiums generates an increase in financing costs that can jeopardize the solvency of States.

\section{MODEL IMPLICATIONS}

The implications of the model are broadly related to the need to develop the domestic financial market in developing countries in order to facilitate the trade-off between foreign currency debt and foreign currency debt.

The presence of currency mismatches and its adverse effects in terms of increased public debt in the event of a sharp appreciation of the foreign currency leads to the establishment of domestic markets, mainly in local currency, in these countries. The development of local bond markets should then be a new stage in the evolution of financing methods in developing countries. It stems from the usefulness of domestic public debt in domestic financial development. Indeed, the literature accepts that the government's recourse to domestic debt helps to establish a yield curve that can serve as a benchmark for private market operations (Ajili, Ayoub, \& Raffinot, 2013; Saint-Paul, 1994). More specifically, one of the advantages of the public debt market is that it is a prerequisite for the private debt market, since the yield on government securities, which are generally the least risky financial assets, serves as a benchmark for bonds and other debt instruments of public or private corporations.

However, in these countries, the local bond market has not yet reached a level that can compete with external financing due to several obstacles. Indeed, the development of the domestic financial market faces obstacles of a structural nature. These obstacles are broadly of two kinds: internal structural obstacles, on the one hand; and external structural obstacles, on the other. With regard to internal obstacles, two types can be distinguished. On the one hand, there is the high level of default risk for issuers, both public and private. On the public issuer side, although improved public financial management can reduce sovereign risk, the payment history of developing country governments, marked for many of them by the accumulation of large domestic arrears, leads to a specific perception of risk among local investors. And on the other hand, the lack of critical size, in terms of liquidity and depth of existing markets, which results in high issuance and, above all, transaction costs, due to the importance of fixed costs. The non-existence or lack of depth of secondary markets, including the interbank segment, is also at the origin of a high risk of liquidity and price volatility.

As for external structural obstacles, four of them can be identified overall. First, a lack of reliable and structured information. This deficit stems from a lack of market culture and, more fundamentally, from the low level and, in some cases, deterioration of information systems (statistics, company accounting). In particular, it is reflected in the absence or inadequacy of reliable, accessible and regularly published data, and in the little widespread practice of risk rating.

Secondly, the weakness of local demand due to:

- A low rate of financial savings, a consequence of a very unequal distribution of income, a bias of the wealthiest categories for investment abroad and the inadequacy of collective savings mechanisms, particularly pension systems.

- A weak development of institutional investors, with the exception of banks.

Then, an institutional, legal and regulatory framework that is partly unsuitable: the inadequacy of rules on transparency and governance of governments and companies, the length of administrative procedures governing market access or certain regulatory provisions are all obstacles to the development of debt securities markets.

Finally, a lack of know-how and competence on the supply side (issuers), the demand side (institutional investors, but also under-information of individual investors) and especially on the intermediaries' side, a consequence of insufficiently developed financial systems.

Furthermore, the development of the interbank market should be facilitated by the development of the regional bond market, which should provide suitable support for interbank transactions, particularly repurchase agreements, provided that an appropriate legal framework is put in place. 
However, the development of these markets should be accompanied by an accumulation of foreign exchange reserves to facilitate the repayment of public debt denominated in foreign currency. Indeed, the accumulation of foreign exchange reserves constitutes an effective hedging instrument for exchange rate management. Adequate foreign exchange reserves thus enable the State to borrow abroad without running the risk of sovereign default. There are two main advantages: on the one hand, it provides a buffer of liquidity and security and, on the other hand, by allowing loans to be repaid, it loosens the external debt constraint that limits governments' room for maneuver (or even makes them subject to the "conditionality" of the International Monetary Fund). Thus, in developing countries with limited access to international financial markets, foreign exchange reserves provide a buffer for the settlement of imports and the servicing of foreign currency external debt.

\section{CONCLUSION}

We have shown, based on a partial equilibrium theoretical model, that the public debt management strategy in the presence of currency mismatches depends on three cases when the government's objective is to minimize the interest burden. First, it is preferable for governments to issue more debt in local currency and less debt in foreign currency when the domestic interest rate is lower than the risk premium on external debt. Second, when the premium is lower, the best strategy is to use foreign currency debt. Finally, there may be a situation where managers must use both types of instruments in identical proportions. However, for developing countries, for which foreign currency debt represents a large share of the public debt portfolio, case 1 is the optimal strategy. Indeed, we know that a large foreign currency debt is accompanied by high exchange rate risk and therefore high-risk premiums. Recourse to more domestic debt is particularly important for these countries because of the weak development of financial markets. Indeed, as noted above, the literature accepts that the government's recourse to domestic debt helps to establish a yield curve that can serve as a reference for private market operations. More specifically, one of the advantages of the government debt market is that it is a prerequisite for the private debt market, since the yield on government securities, which are generally the least risky financial assets, serves as a benchmark for bonds and other debt instruments of public or private corporations.

Funding: This study received no specific financial support.

Competing Interests: The author declares that there are no conflicts of interests regarding the publication of this paper.

\section{REFERENCES}

Aizenman, J., \& Marion, N. (2011). Using inflation to erode the US public debt. Journal of Macroeconomics, 33(4), 524541.Available at: https://doi.org/10.1016/j.jmacro.2011.09.001.

Ajili, W., Ayoub, H., \& Raffinot, M. (2013). Domestic public debt and financial development in the context of Mediterranean countries: The case of Lebanon and Tunisia. Financial Techniques and Development, 110(1), 45-65.

Angeletos, G.-M. (2002). Fiscal policy with noncontingent debt and the optimal maturity structure. The Quarterly Journal of Economics, 117(3), 1105-1131.Available at: https://doi.org/10.1162/003355302760193977.

Artus, P. (2003). Local currency or foreign currency debt ? Economic Review, 54(5), 1013-1031.Available at: https://doi.org/10.3917/reco.545.1013.

Blommestein, H. J., \& Santiso, J. (2007). New strategies for emerging domestic sovereign bond markets in the global financial landscape. Global Economy Journal, 7(2), 1-55.Available at: https://doi.org/10.2202/1524-5861.1276.

Bordo, M. D., Meissner, C. M., \& Stuckler, D. (2016). Foreign currency debt, financial crises and economic growth: A long-run view. Journal of International Money and Finance, Elsevier, 29(4), 642-665.

Buera, F., \& Nicolini, J. P. (2004). Optimal maturity of government debt with incomplete markets. Journal of Monetary Economics, $51(3), 531-554$. 
Burger, J. D., Warnock, F. E., \& Warnock, V. C. (2012). Emerging local currency bond markets. Financial Analysts Journal, 68(4), 73-93.

Calvo, G., Izquierdo, A., \& Mejia, L. F. (2008). Systematic sudden stops. relevance of balance sheet effects and financial integration. NBER Working Paper No 14026.

Carrera, C., \& Vergara, R. (2012). Fiscal sustainability: The impact of real exchange rate shocks on debt valuation, interest rates and GDP growth. World Development, 4O(9), 1762-1783.Available at: https://doi.org/10.1016/j.worlddev.2012.04.024.

Eichengreen, B. R., \& Hausmann, E. P. U. (2003). Original sin: Calvary, the mystery and the path to redemption. Economic Neres, 79(4), 419-455.Available at: https://doi.org/10.7202/010561 ar.

Goldberg, L. S., \& Tille, C. (2016). Micro, macro, and strategic forces in international trade invoicing: Synthesis and novel patterns. Journal of International Economics, 102, 173-187.Available at: https://doi.org/10.1016/j.jinteco.2016.07.004.

Goldstein, M., \& Turner, P. (2004). Controlling currency mismatches in emerging markets. Washington, D.C: Peterson Institute for International Economics.

Hausmann, R., \& Panizza, U. (2011). Redemption or abstinence? Original sin, currency mismatches and counter cyclical policies in the new millennium. Journal of Globalization and Development, 2(1), 1-33.Available at: https://doi.org/10.2202/19481837.1127.

Hussein, K. A., \& de Mello Jr, L. R. (2001). Is foreign debt portfolio management efficient in emerging economies? Journal of Development Economics, 66(1), 317-335.Available at: https://doi.org/10.1016/s0304-3878(01)00165-1.

Jankovic, I., \& Zivković, B. (2014). An analysis of the effect of currency mismatch on a country's default risk. Economic Annals, 59(201), 85-121.Available at: https://doi.org/10.2298/eka1401085j.

Melecky, M. (2008). An alternative framework for foreign exchange risk management of sovereign debt. Policy Research Working Paper No 4458.

Melecky, M. (2012). Choosing the currency structure of foreign-currency debt: A review of policy approach. Journal of International Development, 24(2), 133-151.Available at: https://doi.org/10.1002/jid.1711.

Papaioannou, M. G. (2009). Exchange rate risk measurement and management: issues and approaches for public managers. South-Eastern Europe Journal of Economics, 7(1), 7-34.

Prasetyo, A. D., \& Yoshino, N. (2015). Determining the optimal structure of government debt in Indonesia. Global Business and Economics Review, 17(4), 445-466.Available at: https://doi.org/10.1504/gber.2015.072499.

Prat, S. (2007). The relevance of currency mismatch indicators: An analysis through determinants of emerging market spreads. Economie Internationale, 11(3), 101-122.Available at: https://doi.org/10.3917/ecoi.111.0101.

Ranciere, R., Tornell, A., \& Vamvakidis, A. (2010). Currency mismatch, systemic risk and growth in emerging Europe. Economic Policy, 25(64), 597-658.

Saint-Paul, G. (1994). Public debt as a driver of financial development. Economic Review, 45(3), 767-774.

Svensson, L. E. (2000). Open-economy inflation targeting. Journal of International Economics, 50(1), 155-183.

Togo, E. (2007). Coordinating public debt management with fiscal and monetary policies: An analytical framework. The World Bank Policy Research, No 4369.

Venkatesh, H., \& Hiremath, G. S. (2020). Currency mismatches in emerging market economies: Is winter coming? Bulletin of Monetary Economics and Banking, 23(1), 25-54.

Yilmaz, B. E. (2018). Domestic original sin in public debt management: The case of Turkey (1996-2016). Akdeniz I.I. B.F. Magazine, 18(38), 240-256.Available at: https://doi.org/10.25294/auiibfd.492747. 